\title{
Bazı Odun Sirkelerinin Bitki Patojeni Bakteriler Üzerine Antibakteriyel Etkisinin Araştırılması
}

\author{
Erdal ÖĞÜN ${ }^{1}$, İbrahim KOÇ ${ }^{2 *}$ \\ ${ }^{1}$ Van Yüzüncü Yll Üniversitesi, Fen Fakültesi, Moleküler Biyoloji ve Genetik Bölümü, 65090, Van. \\ ${ }^{2}$ Bitlis Eren Üniversitesi, Mühendislik-Mimarlık Fakültesi, Çevre Mühendisliği Bölümü, 13000, Bitlis \\ (ORCID: 0000-0001-8280-4245) (ORCID: 0000-0003-0803-6801)
}

\begin{abstract}
$\ddot{O} z$
$\mathrm{Bu}$ araştırmada, findık kabuklarından ve tavuk gübresinden elde edilen odun sirkelerinin bazı bitki patojeni bakterilere karşı antibakteriyel potansiyeli belirlenmeye çalışılmıştır. Test mikroorganizması olarak, Erwinia amylovora, Pseudomonas syringae pv. lachrymans ve Xanthomonas axonopodis pv. phaseoli kullanılmıştır. Antimikrobiyal aktivitenin belirlenmesinde agar well difüzyon ve makro broth dilüsyon yöntemleri kullanıldı. Agar well difüzyon yönteminin uygulanması sonucunda; E. amylovora suşu, sırasıyla findık sirkesinin \%40, $\% 50$ 'lik seyreltmelerine ve stok solüsyonuna hassasiyet gösterirken, $P$. syringae pv. lachrymans ve $X$. axonopodis pv. phaseoli şuşlarının $\% 30, \% 40, \% 50$ 'lik seyreltmelere ve stok solüsyonuna hassasiyet gösterdiği belirlenmiştir. Broth dilüsyon yöntemi ile minimal bakterisidal konsantrasyonun belirlenmesinde; minimal bakterisidal konsantrasyonun tespiti için yapılan çalışmalar sonucunda, findık sirkesinin E. amylovora, X. axonopodis pv. phaseoli ve $P$. syringae pv. lachrymans üzerindeki MBC değerinin, \%50'lik seyreltmeye eşdeğer olduğu tespit edilmiş̧tir. Yapılan ANOM testi sonucuna göre Doz $\times$ Tür interaksiyon etkisinin önemli olduğu $(\mathrm{P}=0.000)$, dolayısıyla uygulanan dozların inhibisyon değerlerine etkisinin türlere göre önemli değiş̧iklikler gösterdiği saptanmıştır. Antibakteriyel aktivite çalışmaları sonucunda, bitki patojeni bakterilerin findık kabuklarından üretilen sirkeye karşı duyarlı oldukları görülürken, tavuk gübresinden üretilen sirkeye karşı dirençli oldukları gözlemlenmiştir.
\end{abstract}

Anahtar kelimeler: Antibakteriyel aktivite, Bitki koruma, Erwinia amylovora, Pseudomonas syringae pv. lachrymans, Xanthomonas axonopodis pv. phaseoli, Odun sirkesi.

\section{Investigation of Antibacterial Effect of Some Wood Vinegars on Plant Pathogen Bacteria}

\begin{abstract}
In this study, the antibacterial potential of wood vinegar obtained from hazelnut shells and poultry manure against some plant pathogenic bacteria was tested. Erwinia amylovora, Pseudomonas syringae pv. lachrymans and Xanthomonas axonopodis pv. phaseoli strains were used as test microorganisms. Agar well diffusion and broth dilution methods were used to determine antimicrobial activities. For Agar well diffusion method; E. amylovora strains reacted to $40 \%, 50 \%$ dilutions and stock solution of hazelnut vinegar. Furthermore P. syringae pv. lachrymans and $X$. axonopodis pv. phaseoli displayed responses to 30\%, 40\%, 50\% dilution and stock solution. In the determination of minimal bactericidal concentration by broth dilution method; studies conducted to the determination of minimal bactericidal concentration, MBC value of vinegar (from hazelnut shell) on E. amylovora, $X$. axonopodis $p v$. phaseoli and $P$. syringae pv. lachrymans strains was found to be equivalent to $50 \%$ dilution. According to the ANOM test results, Dose $\times$ Species interaction effect was significant $(\mathrm{P}=0.000)$, therefore, the effect of administered doses on inhibition values showed significant changes from species to species. As a result of antibacterial activity studies, it was observed that plant pathogenic bacteria were susceptible to vinegar produced from hazelnut shells while they were resistant to vinegar produced from poultry manure.
\end{abstract}

Keywords: Antibacterial, Plant protection, Erwinia amylovora, Pseudomonas syringae pv. lachrymans, Xanthomonas axonopodis pv. phaseoli, Wood vinegar.

*Sorumlu yazar: ibrahimkoc47@ gmail.com

Geliş Tarihi: 06.08.2019, Kabul Tarihi: 25.09.2019 


\section{Giriş}

Tarım sektörü, dünyada önemini korumakta ve gelecekte de korumaya devam edecektir [1]. Turabi'ye atfen tarımda hastalık, zararlı ve yabancı otların kalite ve verimi düşürdüğü, pestisitlerin kullanılmaması durumunda \%60'lara varan oranlarda ürün kayıplarının olabileceği bildirilmiştir [2]. Bitkilerde genel olarak hastalığa sebep olan bitki patojeni bakteriler, Xanthomonadaceae, Pseudomonadaceae ve Enterobacteriaceae familyalarına ait olup bu patojenler kendilerine bazı bitki türlerini konakçı olarak seçerek, hedef alabilirler [3]. P. syringae, X. oryzae pv. oryzae, X. axonopodis pv. manihotis, X. campestris ve E. amylovora patojen bakteri türleri bitkilere ciddi derecede zarar vermektedir [4]. Modern tarımsal üretimde pestisitler vazgeçilmez öneme sahiptir [5]. Ancak, günümüzde tarımsal ürünlerdeki pestisit kalıntılarının varlığı ve bunların trofik ağa girişleri insan sağlığını ve çevreyi tehlikeye atmıştır [6]. Tarımsal uygulamaların başlıca amacı ekolojik dengelere zarar vermeden kaliteli ve bol ürün almaktır [7]. Fakat sentetik pestisitlerin yoğun kullanımından dolayı ortaya çıkan sorunlar, bitki koruma çalışmalarında alternatif yöntemlerin ve doğal pestisitlerin aranmasını elzem hale getirmiştir [8]. Odun sirkesi (OS); karbonizasyon işlemler sonucu üretilen [9, 10], ve arkeolojik çalışmalarda Neanderthal zamanında biyopestisit olarak kullanıldığı tespit edilen bir üründür (pyrolysis liquids) [10]. Mu ve arkadaşları [11], OS'ın organik tarım için iyi bir kaynak olduğunu ve Japonya'da tarım ile günlük hayatta geniş bir şekilde kullanıldığını bildirmişlerdir. Jang'a atfen, OS 'ın \%80-90'1 su, \%10-20'sinin 200'den fazla organik birleşikten oluştuğu bildirilmiştir [12]. Chalermsan ve Peerapan [13], OS'ın bitki korumada patojenik bakterilere karşı umut verici bir çözelti olduğunu saptamışlardır. Eric ve arkadaşları [14], OS'ın bakterileri inhibe ettiğini ve özellikle gram pozitiflerin, negatiflere göre daha hassas olduğunu ifade etmişlerdir. Koç [15], in-vitro şartlarında toprak florasında bulunan gram pozitif bakteri izolatları için tavuk gübresinden elde ettiği OS' konsantrasyon (MIK) değeri olduğunu bildirmiştir. Nurhayati ve arkadaşları [9], A. mangium'dan elde ettikleri OS'un $P$. aeroginosa ve $S$. aureus'a karşı antimikrobiyal etkisinin olduğunu bulmuşlardır. Chukeatirote ve Jenjai [16], D. longan'dan ürettikleri OS'un 14 bakteri suşuna karş1 antibakteriyel aktivite gösterdiğini tespit etmişlerdir. De Souza Araújo ve arkadaşları [17], çoklu antibiyotik direncine sahip E. coli, $P$. aeruginosa ve $S$. aureus'un $M$. tenuiflora ve E. urophylla $\times$ E. grandis karışımından elde ettikleri OS'a karşı hassasiyet gösterdiğini, $15-25$ mm çap aralığında inhibisyonların oluştuğunu ve OS'un \%20 konsantrasyonda bile mikroorganizmaları inhibe ettiğini gözlemlemişlerdir. Duan ve arkadaşları [18], çalışmalarında kullandıkları dört çeşit OS'un E. coli, S. aureus ve B. subtilis bakterileri üzerinde en güçlü engelleyici etkiye sahip olduğunu ifade etmişlerdir. Yang ve arkadaşları [19], $L$. chinensis'den elde ettikleri OS'un bir grup antibiyotiğe dirençli izolatlara karşı etkili olduğunu (15-19 mm geniş spektrumlu inhibisyon zonları oluştu) ve OS'un antibakteriyel etkinliğinin yüksek fenolik bileşimlerinden kaynaklanabileceğini bildirmişlerdir. Mao ve arkadaşları [20], acı badem kabuğundan ürettikleri OS'un anti-patojen aktivitesi gösterdiğini ve bu durumun fenol, asetik asit ve furfural'dan kaynaklı olduğunu düşünmektedirler. Baimark ve Niamsa [21], OS'ın antifungal etkililiğinin güçlü fenolik bileşikler içermesinden kaynaklandığını bildirmiştir. Namlı ve arkadaşları [22], OS'un biyosit olarak in-vivo koşullarda denenmesinin yararlı sonuçlar verebileceği kanısına varmışlardır. Laboratuar çalışmaları dışında Shi [23], OS'un özellikle sebzelerin kök bölgesindeki bakterilerin sayısının artmasında teşvik edici olduğunu; Koç [15], çalışmasında tavuk gübresinden üretilen OS'un, toprakta bulunan bakteri populasyonlarını istatistiksel olarak önemli düzeylerde etkilemediğini $(\mathrm{P}>0.436)$ bildirmişlerdir. Tiilikkala ve arkadaşları [10], pyrolysis sıvılar'ın, atıkların ve biyokütlenin sürdürülebilir kullanımında uygulanabilir bir teknik olmasından dolayı önemi ve sosyal etkisi'nin artırılabileceği, gelecekte biyo-ekonomi temelli bilgiye ve biyo-ekonominin gelişmesine bağlı olarak sentetik kimyasalların yerini alabileceğini ifade etmişlerdir. Kim ve arkadaşları [12], OS'un son zamanlardaki yıllık üretiminin 14.000 ton civarında olduğunu bildirmişlerdir.

$\mathrm{Bu}$ çalışma, tavuk gübresi ve fındık kabuklarından üretilen odun sirkelerinin bazı bitki patojeni bakteri türlerine karşı antibakteriyel potansiyelini belirlemek amacıyla yapılmıştır. 


\section{Materyal ve Metot}

\subsection{Materyal}

\subsubsection{Araştırmada kullanılan besiyerleri, mikroorganizmalar ve odun sirkeleri}

$\mathrm{Bu}$ araştırmada kullanılan Mueller-Hinton Broth, Mueller-Hinton Agar besiyerleri ve Siprofloksasin $(5 \mu \mathrm{g})$ diskleri Oxiod Limited şirketinden, yerel medikal firmalar yoluyla temin edildi. Araştırmada kullanılan Erwinia amylovora, Pseudomonas syringae pv. lachrymans ve Xanthomonas axonopodis pv. phaseoli patojen bakteri suşları (doğal ortamdan izole edilmiş) Van Yüzüncü Yıl Üniversitesi Ziraat Fakültesinin Bitki Koruma Bölümü'nden sağlandı. Odun sirkeleri; Broyler tavuk yetiştiriciliği atığ1 (tavuk gübresi) ve fındık kabuklarından gazlaştırma makinesi ile biyokömür ve odun sirkesi ürünlerini geliştiren bir firmadan alındı [22].

\subsection{Yöntem}

\subsubsection{Odun sirkelerinin agar well difüzyon methodu ile antimikrobiyal aktivitenin tespiti}

Odun sirkelerinin antimikrobiyal aktivitelerinin belirlenmesinde; Balouiri ve arkadaşları [24], tarafindan önerilen agar well difüzyon yöntemi kullanıldı. Bu amaçla; patojen bakteri suşlarının 24 saatlik kültürlerinin bulanıklığı, McFarland skalasının 0.5 numaralı tüpüne göre ayarlandı [25]. Sonra, standart bulanıklığa sahip kültürlerinden, Mueller-Hinton Agar ortamının yüzeyine, $100 \mu 1$ eklendi ve eğri cam çubuk yardımı ile yüzeye yayıldı. Ardından Cork Borer yardımı ile ortamın yüzeyinde $10 \mathrm{~mm}$ çapında kuyucuklar açıldı. Açılan kuyucuklara, odun sirkelerinin stok solüsyonları ile stok solüsyonun distile su ile seyreltilmiş, $\% 10, \% 20, \% 30, \% 40$ ve $\% 50$ 'lik seyreltmelerinden $50 \mu 1$ tatbik edildi. Kontrol antibiyotiği olarak, siprofloksasin $(5 \mu \mathrm{g})$ kullanıldı. Petri plaklar $35^{\circ} \mathrm{C}$ 'de 24 saat inkübasyona birakıldı. İnkübasyonu müteakip kuyucukların etrafında oluşan inhibisyon zonlarının çapları milimetrik cetvel yardımı ile ölçüldü.

\subsubsection{Odun sirkelerinin makro broth dilüsyon yöntemi ile minimal inhibitör ve minimal bakterisidal konsantrasyonun belirlenmesi}

Agar well difüzyon yöntemi sonucunda antibakteriyel etkiye sahip, odun sirkelerinin, bitki patojeni bakteri suşları üzerindeki, minimal inhibitör konsantrasyonun (MIC) ve minimal bakterisidal konsantrasyonun (MBC) belirlenmesinde; Reller ve arkadaşları [26], tarafindan önerilen makro broth dilüsyon yöntemi kullanıldı. Bu amaçla sırasıyla; sekiz tüpten oluşan, tüp serisi hazırlandı. MuellerHinton Broth içerisinde odun sirkelerinin son konsantrasyonu, $\% 20, \% 25, \% 30, \% 35, \% 40, \% 45$ ve $\% 50$ olacak şekilde hazırlandı. Pozitif kontrol için eşit hacimde, Muller-Hinton Broth kullanıldı. Tüplerin tümüne, yukarıda bahsedilen bulanıklığı MacFarland skalasının 0.5 numaralı tüpüne göre hazırlanmış standart kültürlerinden $100 \mu 1$ aşılandı [25]. Ardından tüpler, $35^{\circ} \mathrm{C}^{\prime}$ de 24 saat inkübasyona bırakıldı. İnkübasyon sonrasında tüplerden öze yardımı ile katı besiyerine ekim yapılarak canlılık testi yapıldı. $\mathrm{Bu}$ çalışma tesadüf parselleri deneme deseninde dört tekerrürlü olarak yapılmıştır.

\subsubsection{Verilerin değerlendirilmesi}

Doz ve Türlerin inhibisyon değerlerine etkisinin araştırılmasında Ortalamaların Analizi (ANOM) Tekniğinden [27, 28]. Verilerin istatistik analizlerinde ise Minitab (Ver. 17) istatistik paket programından yararlanılmıştır.

\section{Bulgular ve Tartışma}

\subsection{Agar well difüzyon yöntemi ile tespit edilen antimikrobiyal aktivite sonuçları}

Uygulanan agar well difüzyon yönteminin sonucunda; üç patojen bakteri suşunun, tavuk gübresinden üretilen sirkenin, stok solüsyonu dâhil olmak üzere tüm konsantrasyonlarına direnç gösterdiği belirlendi. 
Ancak findık kabuklarından üretilen odun sirkenin, bazı konsantrasyonlarına karşı, bu bakteri suşlarının, duyarlı olduğu tespit edildi. E. amylovora suşu, sırasıyla findık sirkesinin $\% 40, \% 50$ 'lik seyreltmelerine ve stok solüsyonuna hassasiyet gösterirken, $P$. syringae pv. lachrymans ve $X$. axonopodis pv. phaseoli şuşlarının \%30, \%40, \%50'lik seyreltmelere ve stok solüsyonuna hassasiyet gösterdiği belirlendi. Başka bir değişle findık sirkesinin $P$. syringae pv. lachrymans ve $X$. axonopodis pv. phaseoli üzerindeki en küçük etkili konsantrasyonu \%30 iken E. amylovora'nın üzerindeki en küçük etkili konsantrasyonu \%40 olarak tespit edildi (Tablo 1, Şekil 1a-c).

Tablo 1. Agar weel difüzyon testi sonuçları (Fındık kabuklarından üretilmişs sirke için)

\begin{tabular}{|c|c|c|c|c|c|c|c|}
\hline \multirow{3}{*}{ Patojen Bakteriler } & \multicolumn{6}{|c|}{ Findık Sirkesi Konsantrasyonu (v/v) } & \multirow{2}{*}{$\begin{array}{l}\text { Kontrol } \\
\text { CPR }(5 \mu \mathrm{g})\end{array}$} \\
\hline & Stok Solüsyon & $\% 50$ & $\% 40$ & $\% 30$ & $\% 20$ & $\% 10$ & \\
\hline & \multicolumn{7}{|c|}{ Oluşan inhibisyon zonlarının ortalama değeri mm cinsinden değeri } \\
\hline E. amylovora & $24 \mathrm{~mm}$ & $18 \mathrm{~mm}$ & $15 \mathrm{~mm}$ & Dirençli & Dirençli & Dirençli & $25 \mathrm{~mm}$ \\
\hline P. syringae pv. lachrymans & $22 \mathrm{~mm}$ & $18 \mathrm{~mm}$ & $17 \mathrm{~mm}$ & $12 \mathrm{~mm}$ & Dirençli & Dirençli & $29 \mathrm{~mm}$ \\
\hline$X$. axonopodis pv. phaseoli & $25 \mathrm{~mm}$ & $19 \mathrm{~mm}$ & $18 \mathrm{~mm}$ & $12 \mathrm{~mm}$ & Dirençli & Dirençli & $30 \mathrm{~mm}$ \\
\hline
\end{tabular}

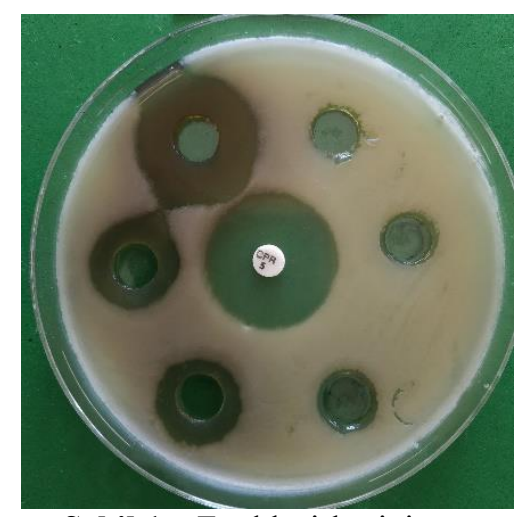

Şekil 1a. Findik sirkesinin $E$. amylovora üzerindeki antibakteriyel etkisi.

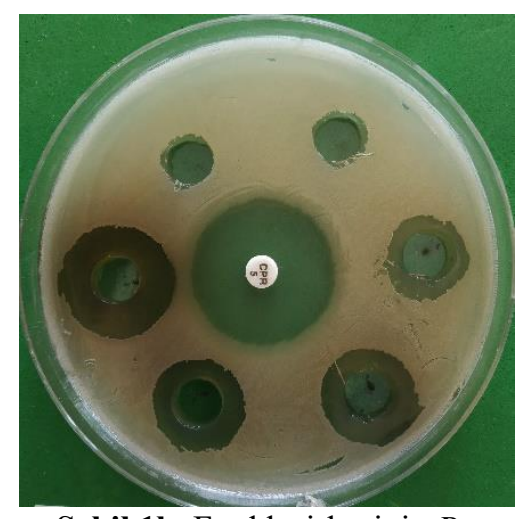

Şekil 1b. Fındık sirkesinin $P$. syringae pv. lachrymans üzerindeki antibakteriyel etkisi.

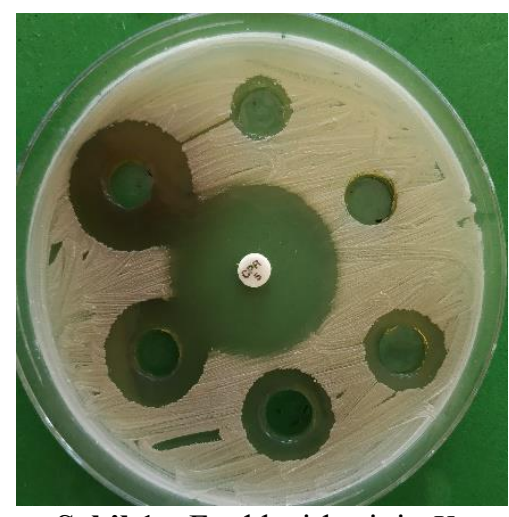

Şekil 1c. Findik sirkesinin $X$. axonopodis pv. phaseoli üzerindeki antibakteriyel etkisi.

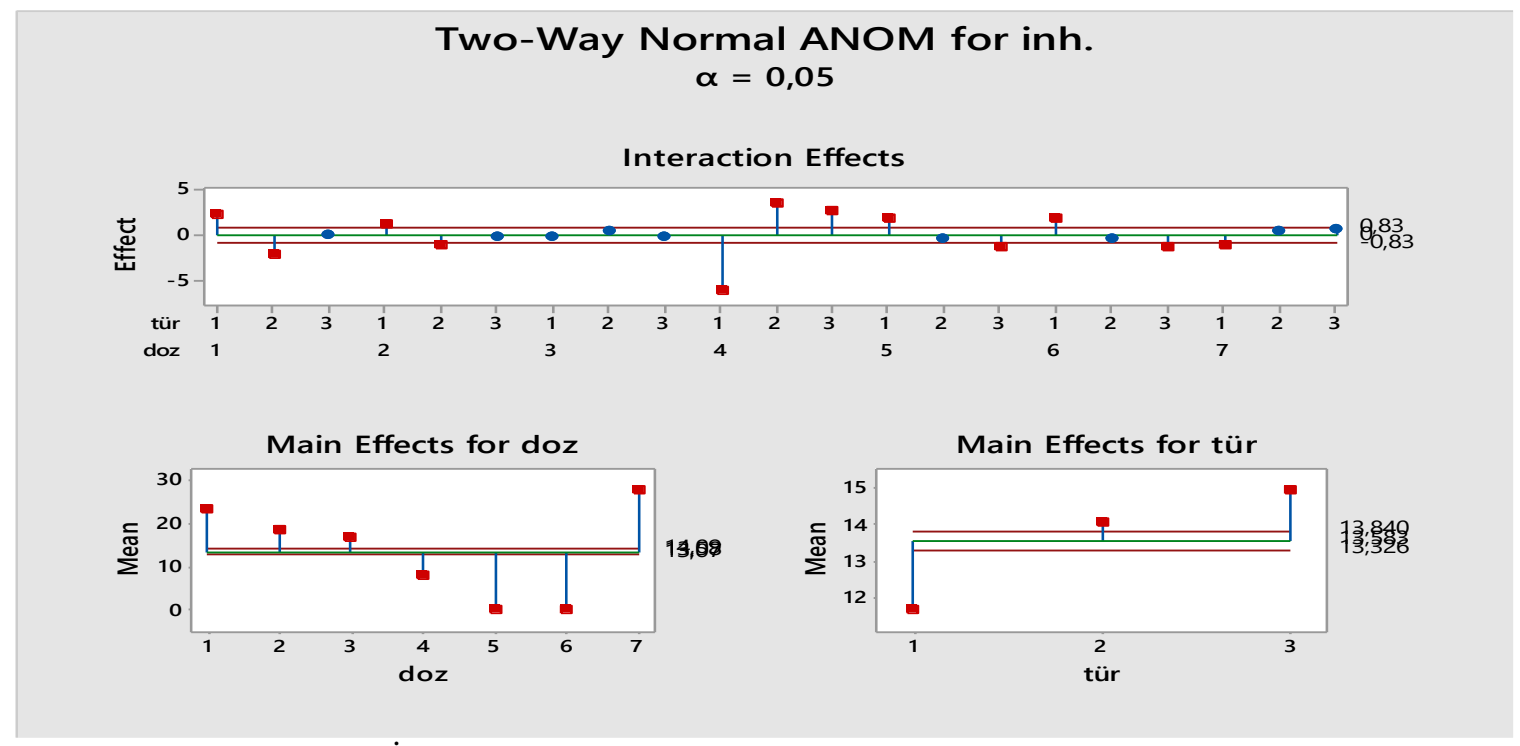

Şekil 2. İnhibisyon çapı bakımından Two-Way Normal ANOM grafiği

Yapılan ANOM testi sonucunda Doz $\times$ Tür interaksiyon etkisinin önemli olduğu $(\mathrm{P}=0.000)$ görülmüştür. Dolayısıyla uygulanan dozların inhibisyon değerlerine etkisi türlere göre önemli değişiklikler göstermiştir. İnteraksiyon grafiği incelendiğinde 1. doz uygulandığında (stok solüsyon) en yüksek inhibisyon değeri $X$. axonopodis pv. phaseoli' de elde edilirken, en düşük inhibisyon değeri ise P. syringae pv. lachrymans'da elde edilmiştir. 2. doz uygulandığında (\%50) en yüksek inhibisyon değeri 
$X$. axonopodis pv. phaseoli türünde, en düşük inhibisyon değerleri $P$. syringae pv. lachrymans ve $E$. amylovora'da görülmüştür. 3. doz uygulamasında (\%40) ise türler arasında istatistiksel olarak önemli farkların bulunmadığı görülmüştür. 4. doz uygulandığında (\%30) en yüksek inhibisyon değerleri $X$. axonopodis pv. phaseoli ve $P$. syringae pv. lachrymans'da görülmüştür. 5. ve 6 . doz sirke uygulamalarında (\%10-20) her üç türünde dirençli olduğu $(0 \mathrm{~mm})$ tespit edilmiştir. Kontrol

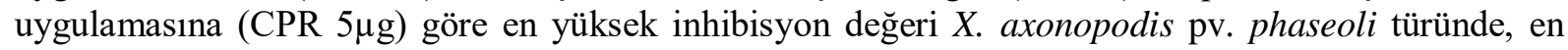
düşük inhibisyon değeri $E$. amylovora'da saptanmıştır. Genel olarak sirkenin, stok solüsyondan seyreltildikçe bakteri türleri üzerindeki etkisinin de azaldığı̆ görülmektedir. Sirkeye karşı en hassas türün X. axonopodis pv. phaseoli olduğu tespit edilmiştir (Tablo 1, Şekil 1c-2). Tavuk gübresinden üretilmiş sirkenin patojenler üzerinde etkili olmadığı görülmüştür (Şekil 3).

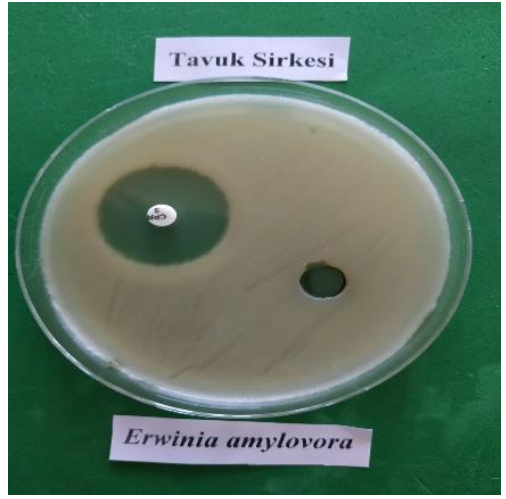

Şekil 3a. Tavuk gübresinden üretilmiş sirkenin (stok solüsyon) E. amylovora üzerindeki antibakteriyel etkisi.

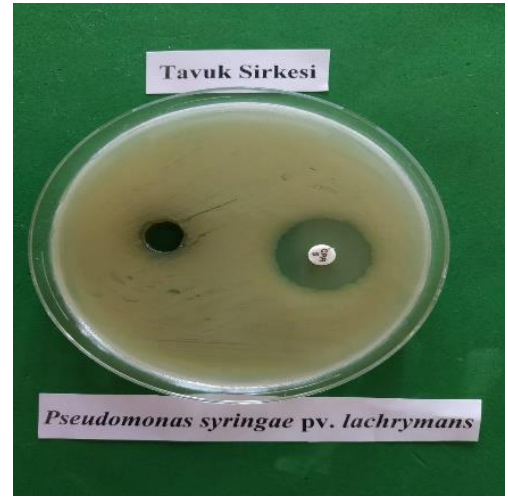

Şekil 3b. Tavuk gübresinden üretilmiş sirkenin (stok solüsyon) $P$. syringae pv. lachrymans üzerindeki antibakteriyel etkisi.

\subsection{Makro broth dilüsyon yöntemi ile tespit edilen minimal bakterisidal etki ile ilgili sonuçlar}

Fındık sirkesinin kendine özgü bir pigmentasyonu (açık kahverengi) olduğundan dolayı broth dilüsyon yöntemi ile MIC değeri çıplak gözle belirlenemedi. Bu yöntemle ancak MBC değeri tespit edilebildi. Fındık sirkesinin E. amylovora, $X$. axonopodis pv. phaseoli ve $P$. syringae pv. lachrymans suşları üzerindeki MBC değerinin, \%50'lik dilüsyona eşdeğer olduğu belirlendi (Tablo 2, Şekil 4a-c).

Tablo 2. Minimal bakterisidal etki ile ilgili test sonuçları.

\begin{tabular}{|c|c|c|c|c|c|c|c|c|}
\hline \multirow[b]{2}{*}{ Patojen Bakteriler } & \multicolumn{7}{|c|}{ Fındık Sirkesi konsantrasyonu (v/v) } & \multirow{2}{*}{$\begin{array}{c}\text { Kontrol } \\
\text { МHB }\end{array}$} \\
\hline & $\% 50$ & $\% 45$ & $\% 40$ & $\begin{array}{c}\% 35 \\
\text { Bakter }\end{array}$ & $\begin{array}{c}\% 30 \\
\text { el Üren }\end{array}$ & \% 25 & $\% 20$ & \\
\hline Erwinia amylovora & - & + & + & + & + & + & + & + \\
\hline Pseudomonas syringae pv. lachrymans & - & + & + & + & + & + & + & + \\
\hline Xanthomonas axonopodis pv. phaseoli & - & + & + & + & + & + & + & + \\
\hline
\end{tabular}

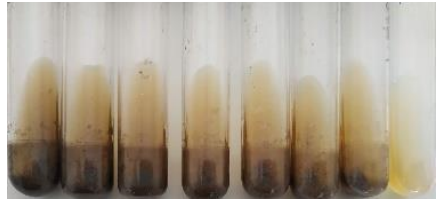

Şekil 4a. Fındık sirkesinin $E$. amylovora üzerindeki MBC değerinin belirlenmesi.

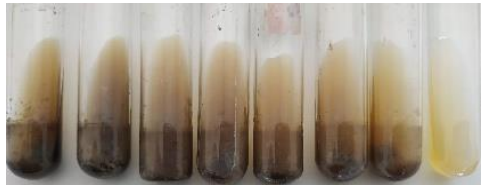

Şekil 4b. Fındık sirkesinin Pseudomonas syringae pv. lachrymans üzerindeki MBC değerinin belirlenmesi.

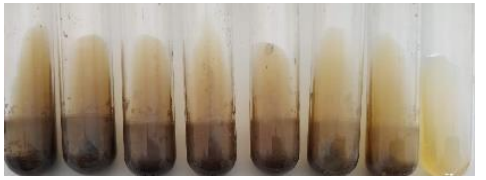

Şekil 4c. Fındık sirkesinin Xanthomonas axonopodis pv. phaseoli üzerindeki MBC değerinin belirlenmesi.

Tarımsal faaliyetlerde kullanılan kimyasal pestisitlerin olumsuz etkileri gün geçtikçe daha ayrıntılı bir şekilde fark edilmektedir. Bu bağlamda organik, doğada çabuk parçalanabilen ve çevredeki canlılara zararı olmayan ürünlere ihtiyaç duyulmaktadır. Bu çalışmada; findık kabuğundan üretilen sirkenin patojen bakterilere karşı etkili olduğu görülmüştür. Ulaşılan bu sonucun in-vitro şartlarında yapılan çalışmaların bulgularıyla örtüştüğü görülmektedir $[9,13,14,16-21]$. Bu olumlu sonucun Yang 
ve arkadaşları [19], Mao ve arkadaşları [20] ile Baimark ve Niamsa [21]'nın çalışmalarında da ifade ettikleri gibi sirkenin sahip olduğu komponentlerden (fenol, asetik asit ve furfural gibi) kaynaklı olduğu düşünülmektedir. Tavuk gübresinden elde edilen sirkenin patojen bakterilere karşı etkili olmadığ tespit edilmiştir. Bu sonucun, Koç [15] ve Koç ve arkadaşları [29]'nın in-vitro şartlarında gram pozitif bakterilere ve $A$. niger ile $P$. digitatum küf etmenlerine karş1 etkili olduğu şeklindeki bulgularıyla örtüşmediği ve bu durumun test edilen bakterilerin dirençleriyle ilgili olabileceği düşünülmektedir. Koç ve arkadaşları [30], findık kabuklarından üretilmiş sirkesinin küf mantarlarını engellemede kullanılabileceğine dair bulguları mevcuttur. Sirkelerin tarımsal amaçlı kullanılmaları durumunda patojenlere karşı etkili aynı zamanda toprak florasında bulunan bakteri popülasyonlarına zarar vermeyeceği Koç [15] ve hatta sebzelerin kök bölgesindeki bakterilerin sayısının artmasında teşvik edici Shi [23] olabileceği düşünülmektedir.

\section{Sonuç ve Öneriler}

Sonuç olarak findık kabuklarından elde edilen sirkenin Tiilikkala ve arkadaşları [10] ile $\mathrm{Mu}$ ve arkadaşlarının [11] ifade ettiği gibi organik tarım için iyi bir kaynak ve zamanla sentetik kimyasalların yerini alabileceği şeklindeki ifadelerinin yanı sıra bitki patojeni bakterilere karşı bakterisidal potansiyeline sahip olduğu düşünülmektedir.

\section{Teşekkür}

$\mathrm{Bu}$ çalışmanın istatistiğinin yapılması ve yorumlanmasında yardımcı olan sayın Prof. Dr. Mehmet MENDEŞ'e, bakteri suşlarının temininde yardımcı olan Dr. Öğr. Üyesi Ahmet AKKÖPRÜ’ye ve odun sirkelerinin temininde yardımcı olan Prof. Dr. Ayten NAMLI'ya teşekkür ederiz.

\section{Kaynaklar}

[1] Arısoy H., Oğuz C. 2005. Tarımsal Araştırma Enstitüleri Tarafindan Yeni Geliştirilen Buğday Çeşitlerinin Tarım İşletmelerinde Kullanım Düzeyi ve Geleneksel Çeşitler ile Karşılaştırmalı Ekonomik Analizi-Konya İli Örneği. T.C. Tarım ve Köyişleri Bakanlığı Tarımsal Ekonomik Araştırma Enstitüsü Yayınları, Yayın No: 130, ISBN: 975-407-174-8, Ankara.

[2] Tiryaki O., Canhilal R., Horuz S. 2010. Tarım İlaçları Kullanımı ve Riskleri. Erciyes Üniversitesi Fen Bilimleri Enstitüsü Fen Bilimleri Dergisi, 26 (2): 154-169.

[3] Kannan V.R., Bastas K.K., Antony R. 2015. Plant Pathogenic Bacteria: An Overview, In Sustainable Approaches to Controlling Plant Pathogenic Bacteria. CRC Press., 16-31.

[4] Mansfield J., Genin S., Magori S., Citovsky V., Sriariyanum M., Ronald P., Dow M., Verdier V., Beer S.V., Machado M.A., Toth I., Salmond G., Foster G.D. 2012. Top 10 Plant Pathogenic Bacteria in Molecular Plant Pathology. Molecular Plant Pathology, 13 (6): 614-629.

[5] Sarmah A.K., Müller K., Ahmad R. 2004. Fate and Behaviour of Pesticides in the AgroecosystemA Review with a New Zealand perspective. Soil Research, 42 (2): 125-154.

[6] Talebi K., Hosseininaveh V., Ghadamyari M. 2011. Ecological Impacts of Pesticides in Agricultural Ecosystem. In Pesticides in the Modern World-Risks and Benefits. InTech., 143-168 pp.

[7] Topal S. 2011. Allelokimyasalların Herbisit Etkileri. Dumlupınar Üniversitesi Fen Bilimleri Enstitüsü Dergisi, 25: 23-26.

[8] Erdoğan P., Toros S. 2005. Melia azaderach L. (Meliaceae) Ekstraktlarının Patates Böceği [Leptinotarsa decemlineata Say (Col.: Chrysomelidae)] Larvalarının Gelişimi Üzerine Etkisi. Bitki Koruma Bülteni, 45 (1-4): 99-118.

[9] Nurhayati T., Roliadi H., Bermawie N. 2005. Production of Mangium (Acacia mangium) Wood Vinegar and Its Utilization. Journal of Forestry Research, 2 (1): 13-25.

[10] Tiilikkala K., Fagernäs L., Tiilikkala J. 2010. History and Use of Wood Pyrolysis Liquids as Biocide and Plant Protection Product. The Open Agriculture Journal, 4 (1): 111-118.

[11] Mu J., Uehara T., Furuno T. 2003. Effect of Bamboo Vinegar on Regulation of Germination and Radicle Growth of Seed Plants. Journal of Wood Science, 49 (3): 262-270. 
[12] Kim D.H., Seo H.E., Lee S., Lee K. 2008. Effects of Wood Vinegar Mixted with Insecticides on the Mortalities of Nilaparvata lugens and Laodelphax striatellus (Homoptera: Delphacidae). Animal Cells and Systems, 12 (1): 47-52.

[13] Chalermsan Y., Peerapan S. 2009. Wood vinegar: By-product from Rural Charcoal Kiln and Its Role in Plant Protection. Asian Journal of Food and Agro--Industry, 189-195.

[14] Eric W., Chan C., Fong C.H., Kang K.X., Chong H.H. 2012. Potent Antibacterial Activity of Wood Vinegar from Matang mangroves, Malaysia. ISME/GLOMIS Electronic Journal, 10 (4): $10-12$.

[15] Koç İ. 2017. Buğday Agro-Ekosistemlerinde Pestisitlerin ve Odun Sirkesinin Bazı Etkilerinin Tespiti Üzerine Bir Araştırma. Yüzüncü Yıl Üniversitesi, Fen Bilimleri Enstitüsü, Doktora tezi, 253 s., Van.

[16] Chukeatirote E., Jenjai N. 2018. Antimicrobial Activity of Wood Vinegar from Dimocarpus longan. Environment Asia, 11 (3).

[17] De Souza Araújo E., Pimenta A.S., Feijó F.M.C., Castro R.V.O., Fasciotti M., Monteiro T.V.C., De Lima K.M.G. 2018. Antibacterial and Antifungal Activities of Pyroligneous Acid from Wood of Eucalyptus urograndis and Mimosa tenuiflora. Journal of Applied Microbiology, 124 (1): 8596.

[18] Duan X., Wang H., Liu Z., Feng C., Cui Y. 2016. Antibacterial Activities of Wood Vinegar from Agricultural and Forestry Wastes Dry Distillation Products. Southwest China Journal of Agricultural Sciences, 29 (2): 425-429.

[19] Yang J.F., Yang C.H., Liang M.T., Gao Z.J., Wu Y.W., Chuang L.Y. 2016. Chemical Composition, Antioxidant, and Antibacterial Activity of Wood Vinegar from Litchi chinensis. Molecules, 21 (9): 1-10.

[20] Mao Q., Zhao Z., Ma X., Li K. 2010. Preparation, Toxicity and Components for Bitter Almond Shell Wood Vinegar. Nongye Jixie Xuebao/Transactions of the Chinese Society of Agricultural Machinery, 41 (2): 164-170.

[21] Baimark Y., Niamsa Y. 2009. Study on Wood Vinegars for Use as Coagulating and Antifungal Agents on the Production of Natural Rubber Sheets, Biomass and Bioenergy, 33: 994-998.

[22] Namlı A., Akça M.O., Turgay E.B., Soba M.R. 2014. Odun Sirkesinin Tarımsal Kullanım Potansiyelinin Araştırılması. Toprak Su Dergisi, 3 (1): 44-52.

[23] Shi Z.Y. 2003. The Effects of Wood Vinegar on Soil Microorganisms and Growth of Vegetable Seedlings. China Agricultural University (People's Republic of China), Master thesis, China.

[24] Balouiri M., Sadiki M., Ibnsouda S.K. 2016. Methods for In Vitro Evaluating Antimicrobial Activity: A review. Journal of Pharmaceutical Analysis, 6 (2): 71-79.

[25] Anonim, 2019. Mcfarland standard For in vitro use only Dalyn Biologicals. Catalogue No. TM50TM60, http://www.dalynn.com/dyn/ck_assets/files/tech/TM53.pdf, (Erişim tarihi: 10.05.2019).

[26] Reller L.B., Weinstein M., Jorgensen J.H., Ferraro M.J. 2009. Antimicrobial Susceptibility Testing: A Review of General Principles and Contemporary Practices. Clinical Infectious Diseases, 49 (11): 1749-1755.

[27] Mendeş M. 2012. Uygulamalı Bilimler İçin İstatistik ve Araştırma Yöntemleri. Kriter Yayınevi, Çanakkale, 664s.

[28] Yiğit S., Mendeş M. 2018. Which Effect Size Measure is Appropriate for One-Way and TwoWay Anova Models? A Monte Carlo Simulation Study. Revstat-Statistical Journal, 295-313.

[29] Koç İ., Yardım E.N., Yıldız Ş. 2017. İn Vitro Şartlarında Küf Etmenlerine Karşı Tavuk Gübresinden Elde Edilmiş Odun Sirkesinin Antifungal Etkisi. Yüzüncü Y1l Üniversitesi Tarım Bilimleri Dergisi, 27 (4): 516-520.

[30] Koç İ., Yardım E.N., Çelik A., Mendeş M., Mirtagioğlu H., Namlı A. 2018. Fındık Kabuklarından Elde Edilmiş Odun Sirkesi'nin In-Vitro Şartlarında Küf Etmenlerine Karşı Antifungal Etkisinin Belirlenmesi. Bitlis Eren Üniversitesi Fen Bilimleri Dergisi, 7 (2): 296-300. 